Effects of Antibiotics on Oestrogen Metabolism

SIR,-Ampicillin, ${ }^{1}$ phenoxymethylpenicillin, ${ }^{2}$ and neomycin ${ }^{3}$ have been shown to decrease urinary oestriol output in normal human pregnancy. We have explored this matter further by employing a new gas chromatographic method ${ }^{4}$ which enables the four known urinary oestriol conjugates to be measured separately. Six healthy mothers 33-37 weeks pregnant were given $0.5 \mathrm{~g}$ of ampicillin orally four times daily on three successive days. The mean urinary oestriol output decreased to an average of $69 \%$ of the pretreatment level on the second, third, and fourth days after starting the ampicillin treatment. The results indicate that the diminished excretion of one conjugate, oestriol-3-glucuronide, accounted for approximately $90 \%$ of this decrease.

Oestriol-3-glucuronide is formed in the intestinal mucosal cells ${ }^{56}$ and its formation is dependent on the reabsorption of biliary oestriol in the intestinal tract. Thus ampicillin interferes with the enterohepatic circulation of oestrogens, impairing the synthesis of oestriol-3-glucuronide. The antibiotic probably exerts its effect by changing the composition of the intestinal microflora. It is of interest that another antibiotic, rifampicin, causes contraceptive failures when given to women taking oral contraceptives (Breuer, personal communication). Thus administration of antibiotics may cause unexpected complications through their effect on oestrogen metabolism.-We are, etc.,

\section{J. TIKKANEN} H. ADLERCREUTZ

Department of Clinical Chemistry,

University of Helsink

M. O. PulkKinen

Department of Obstetrics and Gynaecology

University of Turku,
Finland

1 Willman, K., and Pulkkinen, M. O., American for, 893.

2 Pulkkinen, M. O., and Willman, K., British Medical fournal, $1971,4,48$.

Pulkkinen, M. O., and Willman, K., American fournal of Obstetrics and Gynecology, 1973. In press.

Tikkanen, M. J., and Adlercreutz, H., foumal of Steroid Biochemistry, 1972, 3, 807

Dlinishe C., and Breuer, H., Zeitschrift für 4, 153 .

6 Stoa, K. F., and Levitz, M., Acta Endocrino-

logica, 1968, 57, 657 .

\section{Drowning Accidents in Childhood}

SIR,-I should like to draw attention to a poorly publicized and largely preventable cause of death in children-namely, drowning.

The Royal Life Saving Society has carried out biennial analyses of fatal drowning accidents in the United Kingdom since 196 and, though there are not statistical records, some interesting and disturbing trends should be noted. The 1971 analysis ${ }^{1}$ shows that there has been a small increase in deaths from this cause in the 0-5-year age group since 1961 (118 in 1961; 126 in 1971), with a decrease in deaths in the 6-10-year and 11-15-year age groups, so that in 1971 the 0-5-year group accounted for almost $50 \%(126 / 261)$ of these deaths in ohildhood.

The majority of drowning accidents in homes occur in the 0 -5-year group (34/37 children in 1971), and of particular importance are the number of deaths in ornamental ponds. There were 17 deaths in ornamental ponds, occurring exclusively in the 0-5-year group, in 1971, an increase of seven compared with 1969. Children playing near water accounted for 118 deaths in 1971, and 70 of these occurred in the 0-5-year group. Sixty-nine deaths occurred in inland waters, the majority in rivers, streams, canals, sewerage, and open drains. In all, accidents in homes and to children playing near water, both potentially preventable, accounted for approximately $83 \%(104 / 126)$ of deaths in the 0-5-year group.

A personal retrospective study of freshwater near-drowning in Oxford children confirms the 0-5-year age group to be most at risk. Of 20 children surviving accidenta fresh-water immersion admitted to the Radcliffe Infirmary between January 1961 and December 1972, 13 (65\%) belonged to the 0-5-year group.-I am, etc.,

E. H. SMIth

Radcliffe Infirmary,

Quarterly fournal of the Royal Life Saving Society
United Kingdom, 1972, 7, No. 3.

\section{Rural Dispensing}

SIR,-I feel sure that Dr. B. D. Morgan Williams (Supplement, 24 March, p. 92) will agree that a pharmaceutical service is beneficial to the community. In fact surveys have shown that a large proportion of the public seek advice and treatment for minor ailments from the pharmacist, which in turn cuts down visits to the doctors and relieves expense to the N.H.S.

There are bound to be areas in the most remote parts of the country where it would be impossible to give a pharmaceutical ser vice, but it is surely not economic sense to inconporate dispensing facilities in new health centres when a pharmaceutical service al ready exists a few yards away and rura patients have to pass the pharmacy to obtain their drugs from the surgery. Essential services such as physiotherapy are needed, yet the taxpayer's money is wasted by duplication of other services.

The government spends thousands of pounds on training pharmacists, and the Ministry of Health and Social Security insists that all dispensing in pharmacies mus be under the direct supervision of the pharmacist at all times. There is no similar requirement that a doctor shall do the dispensing himself or that it shall be done under his direct supervision. Nor is the doctor's dispensing subject to the scheme for testing the quality and quantity of medicines supplied, which is applied to all N.H.S. dispensing in a pharmacy. With the implementation of the Medicines Act, this regulation will also apply to all dispensing done in N.H.S. hospitals. Pharmacists are well aware of this need for vigilance, but unfortunately the public in general, and the medical profession, appear to take the view that the dispensing of the potent drugs produced today, with their complexity of dosages, genetic names, and strengths, does not require supervision by a qualified pharmacist. No doubt with entry into the Common Market this situation between the professions will be resolved, because it is recognized by the member states that the dispensing of drugs should be under the supervision of a pharmacist at all times. I am, etc.,

Pocklington, Yorks

DONAH M. SHEPHERD

\section{Doctors and Overpopulation}

SIR,-I crave the use of your columns to draw the attention of members of the B.M.A. to the grievance I have had recently with the Executive Committee of the Bristol Division and which has gained no redress. This concerns the committee's approval of the inclusion in the official B.M.A. mailing in March of advertising literature for the Doctors and Overpopulation Group, comprising the founding letter to the B.M.J. ( 8 January 1972 , p. 108), and the petition for "Population Day."

My objection principally centres on the stated views in that letter regarding the retention and spread (by inference) of "liberal" abortion in the context of population control. The $D$. and $O$. group can be regarded only as a pressure group, members of which have advocated in the press or on television "abortion on demand" as a method of contraception. As I understand it the official policy of the B.M.A. approves of abortion only on medical grounds, and the Bristol Division, by its action in advertising the views of this comparatively small group of doctors, have made a gross departure from the middle ground of medical ethics.-I am, etc.,

Bristol

F. DIFFORD

\section{Consultants' Superannuation}

SIR,-The B.M.A. booklet, N.H.S. Superannuation Scheme, Hospital Medical Officers, $1973^{1}$ is a helpful document; it shows something of the very hard work put in by our negotiators.

I must, however, point out one section that is surely a worsening of a previous position. The calculation for that portion of the superannuation relating to domiciliary consultations is now to be based on "average earnings from domiciliary consultations in the same year as remuneration is taken in calculating the main benefit (my italics); previously the basis was the average of the last three years of service. Almost always the main benefit is most advantageously calculated from the whole-time equivalent of the last year of service, and that means that the domiciliary calculations must now be made from that same year. It is very usual for there to occur a tailing off of domiciliary work in the last year and this yields as a basis for calculation a smaller sum than would be the average of the last three years. Admittedly the basis year is to be multiplied by an eightieth part of all of the years of superannuable service, but this concession is not going to be worth much if the perhaps slightly increased number of years is going to be used to multiply a severely diminished base amount (that is, the small amount of domiciliary fees earned in the last year as opposed to what was earned on average over the whole time that the consultant was doing domiciliary work).

This is not a matter of asking the Government for favours; it is merely a matter of 